\title{
NOVÉ POZNATKY O FACII „PEBBLY MUDSTONES“ PESTRÝCH VRSTEV KROMĚŘİŽSKÉHO SOUVRSTVÍ (KARPAT, STŘEDNÍ ČÁST KARPATSKÉ PŘEDHLUBNĚ)
}

\author{
New findings about the facies of the "Pebbly mudstones" of variegated deposits \\ of Kroměříž Formation (Karpatian, Central part of the Carpathian Foredeep)
}

\author{
Michal Francírek, Martin Hanáček, Slavomír Nehyba \\ Ústav geologických věd, Prírodovědecká fakulta, Masarykova univerzita, Kotlářská 267/2, 61137 Brno; \\ e-mail: francirekmichal@seznam.cz; HanacekM@seznam.cz; slavek@sci.muni.cz
}

(24-42 Kojetín, 25-31 Kroměříž)

Key words: Carpathian Foredeep, Karpatian, Kroměřiž Formation, borehole core, pebbly mudstones, detrital garnet, provenance

\begin{abstract}
One of the facies of variegated deposits of the Kroměr iž Formation (Miocene, Late Karpatian) is represented by pebbly mudstones. The Kroméřž Formation is formed by clays, mudstones, sands, sandstones, gravels and conglomerates. This formation has been deposited along the active margin of the Carpathian Foredeep ahead of the front of the Western Carpathian flysch nappes and is divided into the variegated deposits and the Holešov conglomerates. The variegated deposits are known only from the deep boreholes. In this paper the samples of pebbly mudstones from boreholes Rataje-1, -2 and Kromèr been subjected to the grain size analysis, petrographic and provenance analyses of gravel clasts and analyses of the chemistry and provenance of detrital garnets. The pebbly mudstone from the borehole Rataje-1 contains $\sim 24 \%$ gravel, $\sim 18 \%$ sand and $58 \%$ clay + silt and can be classified (according to Nichols 2009) as a gravelly mudrock. The pebbly mudstone from the borehole Kroměr $̌$ íz-1 is formed by $\sim 2.5 \%$ gravel, $\sim 19 \%$ sand and $\sim 78.5 \%$ clay + silt and is classified as a sandy mudrock. The clasts are mostly formed by quartzs (30-35\%), sandstones (20-27\%), metamorphic rocks (10-20 \%) a magmatic rocks (10-19\%). The clasts of chert (3-12\%) and limestones (1-9\%) are less common. Other rocks as shales, mudstones and menillites are only accessory (representing about $1 \%$ of clasts each). The presence of the clay and silt matrix and also the mudstone intraclasts and rock extraclasts show mixing of the intrabasinal unconsolidated fine-grained deposits and coarse-grained clastic material from the extrabasinal environment. The clasts have subangular and subrounded shape. The predominant type of detrital garnets is Alm-Prp with pyrope component to $20 \%$, which represents $\sim 65 \%$ of detrital garnets. The pebbly mudstones have been interpreted as deposits of cohesive debris flows (being a part of the subaqueous fan or delta?). The flysch nappes of the Western Carpathians served as a source for both clasts and detrital garnets, and deposits of the Kroméř́z Formation are supposed to represent a prograding wedge into the basin.
\end{abstract}

Úvod

Kroměřížské souvrství představuje nejmladší člen sedimentárního záznamu karpatu ve střední části karpatské předhlubně. Bylo uloženo před čely flyšových př́íkrovů, v bezprostředním nadloží novopřerovských vrstev. Souvrství je reprezentováno dvěma členy, tj. holešovskými slepenci a pestrými vrstvami. Holešovské slepence byly dříve také označovány oblastními názvy napřr. nítkovické štěrky a písky, holešovské štěrky atd. (Benada - Kokolusová 1987; Adámek et al. 2003). Slepence jsou známy z vrtů i odkryvů. Naproti tomu pestré vrstvy jsou doloženy pouze $\mathrm{z}$ hlubokých vrtů, které byly provedeny v rámci naftového průzkumu ve 20. století. Typickou facií pestrých vrstev jsou tzv. „pebbly mudstones“. Jsou to sedimenty tvořené příměsí písčité a štěrkovité frakce v jílovité matrix vzniklé z gravitačních hustotních proudů (Reineck - Singh 1973).

Pestré vrstvy byly studovány řadou autorů $\mathrm{v}$ souvislosti s naftovým průzkumem a primární data jsou uložena v archívech průzkumných organizací. Podrobněji se sedimenty pestrých vrstev zabývali Benada - Kokolusová (1987), kteří především studovali jejich petrografii, prostorové rozmístění a vztah $\mathrm{k}$ flyšovým příkrovům Západních Karpat.
$\mathrm{V}$ tomto př́spěvku jsou shrnuty výsledky studia „pebbly mudstones“ pestrých vrstev, zastižených ve vrtech Kroměříž-1, -2 a Rataje-1, -2 (obr. 1). Nové poznatky vyplynuly hlavně $z$ analýz detritických granátů, na jejichž základě byla upřesněna provenience těchto sedimentů.

\section{Metodika}

Studovaná vrtná jádra byla makroskopicky popsána a $z$ jejich psefitické složky byly provedeny valounové analýzy. Z vrtu Kroměřiž-1 (hl. 249 m) bylo analyzováno 437 valounů, ve vrtu Kroměříž-2 (hl. 280 m) 999 valounů a valounová analýza z vrtu Rataje-2 (hl. $314 \mathrm{~m}$ ) obsahovala 1083 klastů. Studované sedimenty byly podrobeny zrnitostní analýze (2 vzorky Kroměříž-1 a Rataje-1), přičemž byla použita síta RETSCH o velikosti oka 2,000-0,063 mm. Analýza byla realizována $\mathrm{v}$ sedimentologické laboratoři Ústavu geologických věd Př́rodovědecké fakulty MU. Vytřídění sedimentů a stupeň zaoblení valounů byly klasifikovány podle Tuckera (2011), zrnitostní složení podle Nicholse (2009). Ze studovaných jader byly odebrány celkem 2 vzorky na analýzy chemismu granátů a to konkrétně z vrtů Kroměříž-1 a Rataje-2. Pro provenienční srovnání byly také nově provedeny analýzy granátů ze ždánicko-hustopečského souvrství ždánické jednotky z vrtu Tlu- 


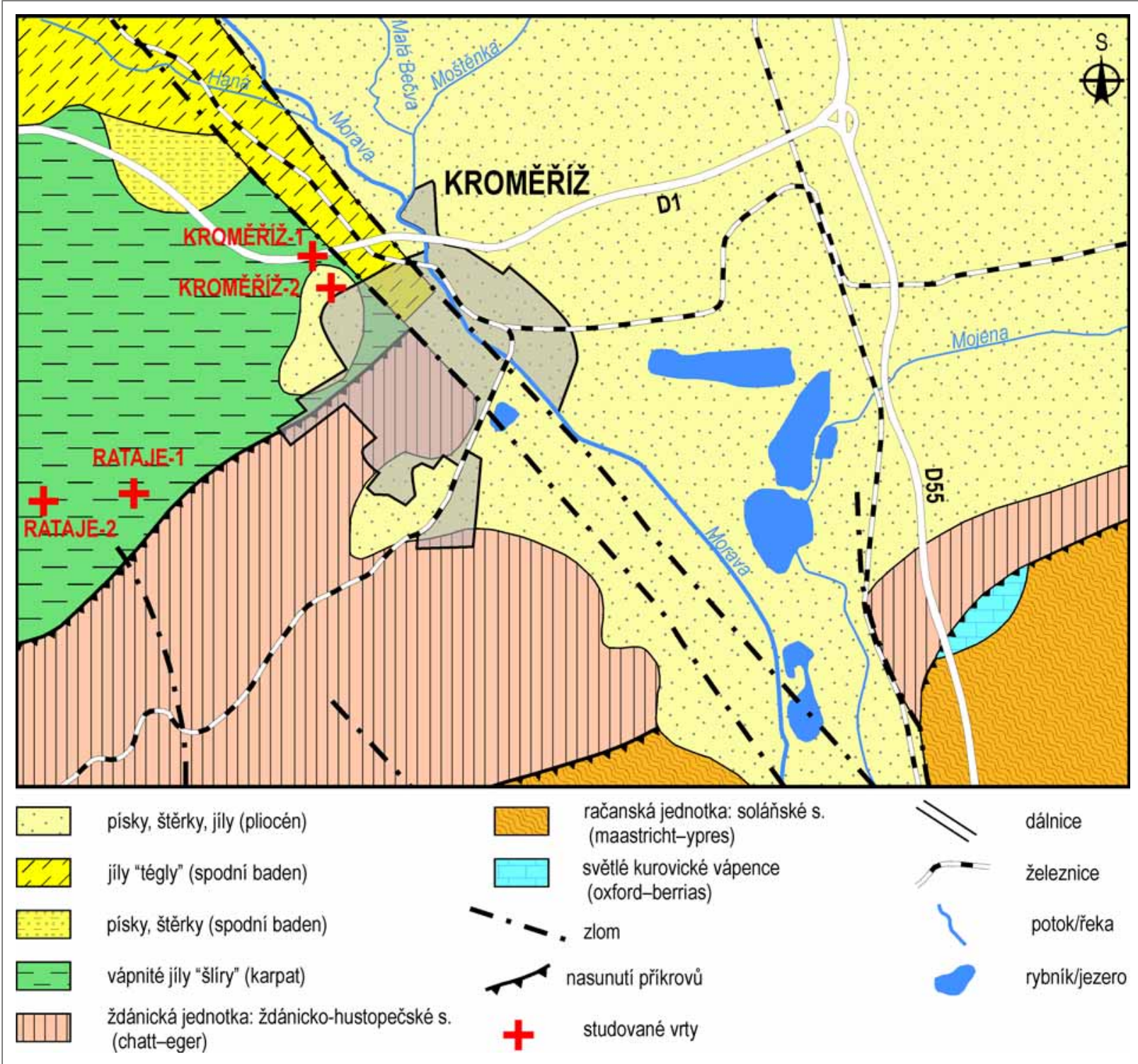

Obr. 1: Lokalizace studované oblasti v geologické mapě (upraveno podle Geologické mapy České republiky $1: 500$ 000, Cháb et al. 2007). Fig. 1: Location of the study area in the geological map (modified after the Geological Map of the Czech Republic 1:500 000, Cháb et al. 2007).

mačov-1 (hl. 502 m). Detritické granáty byly analyzovány na př́stroji CAMECA SX100 na pracovišti elektronové mikroskopie a mikroanalýzy Ústavu geologických věd Př́rodovědecké fakulty MU. Bylo provedeno 20 analýz granátů ze sedimentů pestrých vrstev a 30 analýz granátů ze sedimentů ždánicko-hustopečského souvrství. Výsledky analýz byly vyneseny do ternárních diagramů, jejichž vrcholy tvoří čtyři hlavní koncové členy (almandin, grosulár, pyrop a spessartin). Granáty byly dále rozčleněny do deseti typů podle zastoupení molekul hlavních koncových členů.

\section{Výsledky \\ Granulometrie}

Makroskopicky lze facii „pebbly mudstones“ ve vrtech popsat jako masivní parakonglomeráty (obr. 2A, 2B). Průměrná velikost klastů se pohybuje v rozmezí $1-2 \mathrm{~cm}$, maximálně dosahuje $6 \mathrm{~cm}$. Základní hmota je tvořena světle hnědým prachovitým jílovcem. Zrnitostní složení umožňuje vyčlenit dvě subfacie. První pochází z vrtu Ra- taje-1. Obsahuje 24\% štěrku, 18\% písku a 58\% jílu + siltu (obr. 2G). Podle klasifikace Nicholse (2009) se jedná o štěrkovitý kalovec (gravelly mudrock). Druhá subfacie je z vrtu Kroměříž-1. Obsahuje 2,5\% štěrku, 19\% písku a $\sim 78,5 \%$ jílu + siltu (obr. $2 \mathrm{G}$ ). Podle citované klasifikace jde o písčitý kalovec (sandy mudrock). Facie se tedy odlišují především v podílech štěrkové komponenty.

\section{Valounové analýzy}

Podle složení valounů představují obě facie polymiktní sedimenty (obr. $2 \mathrm{C}$ ). Valouny jsou nejčastěji tvořeny křemenem (30-35\%), pískovci (20-27\%), metamorfity (10-20\%) a magmatity (10-19\%). Nízkými, avšak variabilními podíly jsou zastoupeny rohovce (3-12\%) a vápence (1-9\%). Podíly klastů břidlic, jílovců a menilitu se u každé z hornin pohybují kolem $1 \%$. Jílovce představují intraklasty, ostatní materiál má vněpánevní původ. Valouny jsou poloostrohranné ( 44\%) až polozaoblené ( 36\%). 


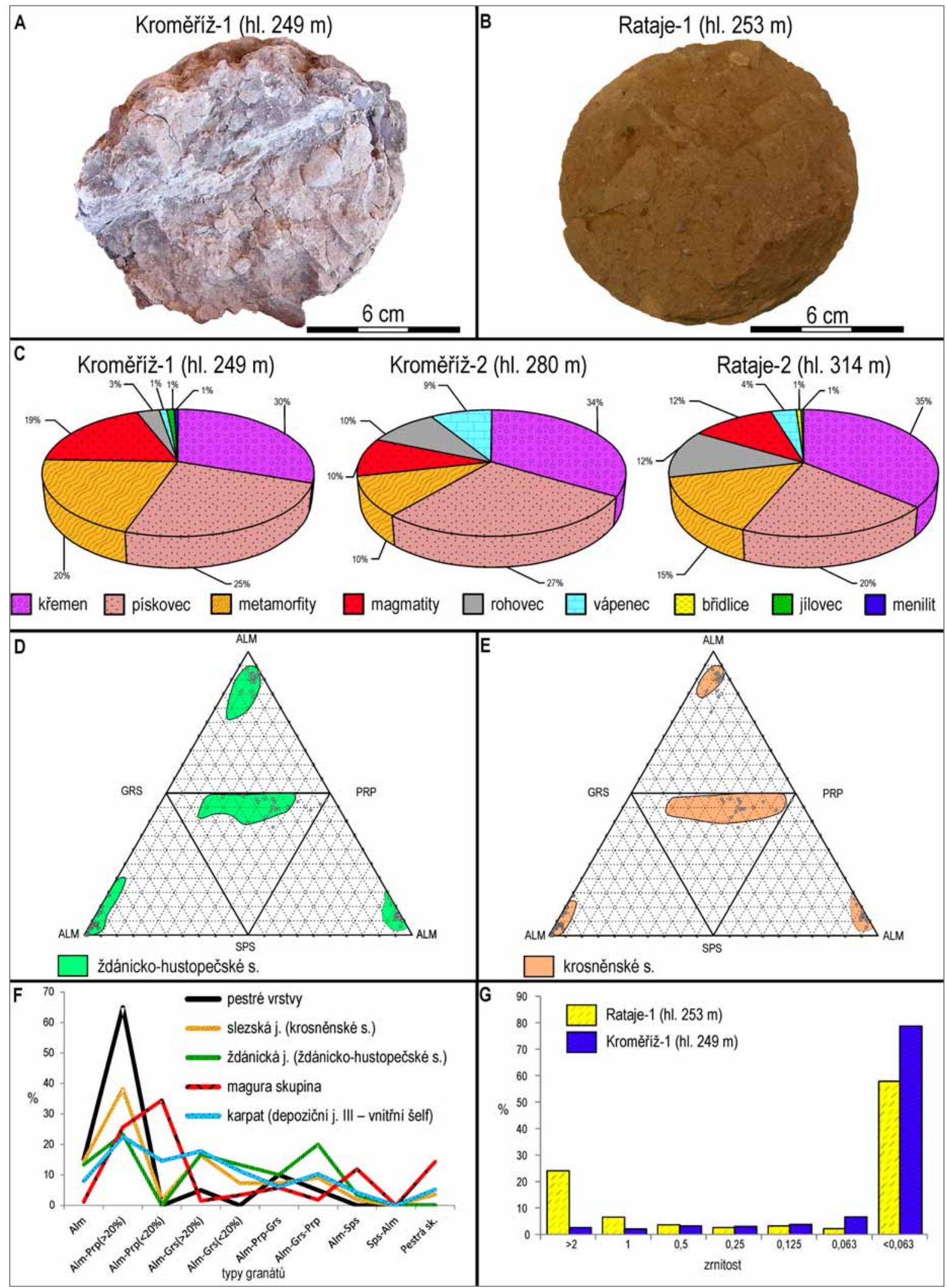

Obr. 2: A - studovaný vzorek z vrtu Kroměříž-1; B - studovaný vzorek z vrtu Rataje-1; C - valounové analýzy; D - chemismus detritických granátů pestrých vrstev kroměřížského souvrství a ždánicko-hustopečského souvrství; E - chemismus detritických granátů pestrých vrstev kroměřížského souvrství a krosněnského souvrství; F -typy detritických granátů pestrých vrstev kroměřížského souvrství a potenciálních zdrojových oblastí; G - zrnitostní analýzy.

Fig. 2: A - Studied sample from the borehole Kroměříž-1; B - Studied sample from the borehole Rataje-1; C - Results of the pebble analysis; D - Chemistry of the detrital garnets of variegated deposits of the Kroměříž Formation and the Ždánice-Hustopeče Formation; E - Chemistry of the detrital garnets of variegated deposits of the Kroměříz Formation and the Krosno Formation; F - Types of the detrital garnets of variegated deposits of the Kroměříz Formation and the potential source areas; G - Results of the grain size analysis. 
Materiál valounů lze makroskopicky popsat následovně. Křemen je převážně světle šedý, méně pak tmavě šedý, bílý a zř́ídka je i nažloutlý. Pískovce jsou jemně až středně zrnité, mají světle šedou až namodralou barvu. Metamorfity jsou představovány hlavně rulami a kvarcity, méně početné jsou klasty fylitů a zelených břidlic. Mezi magmatity dominují světlé granitoidní horniny. Rohovce jsou černé až tmavě šedé. Bílou až bíložlutou barvu mají rohovcové vápence. Klasty jílovců jsou šedozeleně až hnědošedě zbarvené.

\section{Analýzy detritických granátů}

Ve studovaných sedimentech jednoznačně převládají granáty Alm-Prp s obsahem pyropu do $20 \%$ (obr. 2F). Představují 65\% počtu zrn. Druhou nejčastější složkou jsou granáty Alm, jejichž podíl však dosahuje jen 15\%. Zcela akcesoricky se objevují granáty Alm-Grs s obsahem pyropu do $20 \%$ a Alm-Grs-Prp ( 5\%).

\section{Diskuze}

Studované sedimenty jsou součástí mocného, lokálně omezeného kroměřížského souvrství (obr. 3), které kromě facie „pebbly mudstones“ tvoř́i jíly, jílovce, písky, pískovce, štěrky a slepence (Zádrapa 1977; Benada - Kokolusová 1987). Jednotlivé facie se vertikálně různě střídají. Prostorově je kroměřížské souvrství situováno před čelem ždánické jednotky. Paleogeograficky tedy zaujímá pozici okrajových klastik, která lemovala hornatý reliéf zvednutých flyšových př́krovů (Benada - Kokolusová 1987). Dosunutí a zdvih flyšových př́krovů jsou časově kladeny do konce karpatu (Brzobohatý - Cicha 1993). Hrubozrnná klastika v podobné paleogeografické situaci v jiných oblastech jsou interpretována jako uloženiny kuželových delt, podmořských kuželů a skluzových těles (Altermann 1986; Wagreich 2003; Di Celma 2011). Společný výskyt jílovito-siltovité mezihmoty, jílových intraklastů a horninových extraklastů, které jsou zároveň středně zaoblené, naznačuje míchání vnitropánevních nezpevněných jemnozrnných sedimentů a hrubě klastického materiálu pocházejícího z exrapánevního prostředí. Facie tzv. „pebbly mudstones“ vznikala formou kohezních úlomkotoků (Talling et al. 2012). Ve vrstevních sledech bývá spjata s psefity uloženými jako nekohezní úlomkotoky a vysokohustotní turbidity a společně s nimi tvoří např. výplň podmořských kanálů, jimiž byl do pánve přinášen terigenní materiál (Wagreich 2003). „Pebbly mudstones“ nebo jim velmi podobné sedimenty jsou popsány rovněž z úpatních částí (toesetů) hrubozrnných delt (Postma 1984; Sohn et al. 1997), kde se často nahromadily po gravitačním kolapsu deltových čel. Mocnosti pestrých vrstev dosahující až 425 m (Zádrapa 1977) a jejich paleogeografický vztah k čelům př́krovů, lokální omezení a hrubozrnnost celého kroměřížského souvrství napovídají, že studovaná facie „pebbly mudstones" pravděpodobně vznikla v některém $z$ uvedených prostředí. Vyčleněné subfacie štěrkového kalovce a písčitého kalovce se od sebe geneticky nejspíš prríliš neodlišují, protože v „pebbly mudstones“ někdy bývají štěrkové klasty koncentrovány do nezřetelných čoček a pásků (Wagreich 2003), takže jejich distribuce není rovnoměrná.

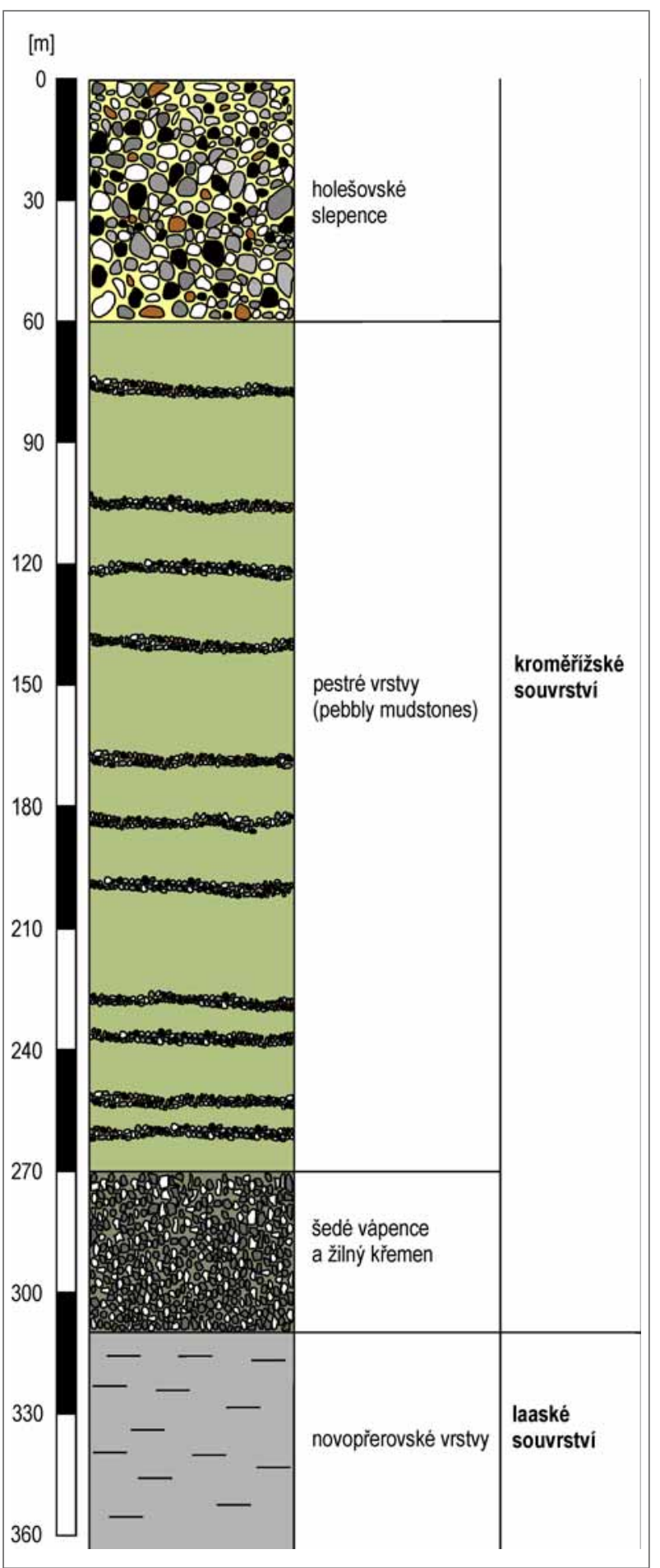

Obr. 3: Zjednodušený litologický profil kroměřížským souvrstvím ve vrtu Kroměříž-1 (upraveno podle Benady et al. 1983; Benady - Kokolusové 1987).

Fig. 3: The simplified lithological profile of the Kroměríz Formation in the borehole Kroměříž-1 (modified by Benada et al. 1983; Benada - Kokolusová 1987).

Valounové složení pestrých vrstev kroměřižského souvrství ukazuje, že zdrojem materiálu těchto sedimentů byly flyšové prŕkrovy Západních Karpat. Původ vápenců lze spatřovat v bradlech vyskytujících se např. u Cetechovic nebo Kurovic. Pískovce pochází ze ždánické jednotky (Benada - Kokolusová 1987). Původ krystalických hornin není zcela znám, ale lze předpokládat, že odpovídá tzv. 
„exotickým“ valounům nacházejících se v príkrovových jednotkách. Chemickým složením tato „exotika“ odpovídají podle Štelcla (1993) podložnímu krystaliniku, avšak Hanžl - Krejčí (1996) shledávají podobnost v granitech moldanubika a Západních Karpat. Na základě zjištěného stáří (346 $\pm 16 \mathrm{Ma}$ ) se podobají granitům tatrika Západních Karpat (Hanžl et al. 1997).

Porovnáním starších publikovaných dat z račanské a slezské jednotky a sedimentů karpatu (Otava et al. 1997; Stráník et al. 2007; Francírek - Nehyba 2016) a nových analýz ždánicko-hustopečského souvrství bylo zjištěno, že se granátová asociace kroměřížského souvrství podobá asociacím z krosněnského souvrství slezské jednotky a ždánicko-hustopečského souvrství ždánické jednotky. Zároveň se odlišuje od granátů račanské jednotky, ve kterých dominují Alm-Prp granáty s obsahem pyropu nad $20 \%$ (obr. 2F). Rozmístění detritických granátů pestrých vrstev kroměřížského souvrství a slezské a ždánické jednotky tvoří v ternárním diagramu liniový trend Prp-Grs (obr. 2D, E). Je možné také uvažovat, že částečně mohl materiál pocházet ze starších sedimentů karpatu tvořících výplň karpatské předhlubně (depoziční jednotka III - vnitřní šelf), jejichž zdrojový materiál pocházel právě ze slezské jednotky (Francírek - Nehyba 2016). Tuto domněnku podporují interpretace Di Celmy (2011), který intepretuje pebbly mudstones jako výsledek kolapsu okrajů šelfu.

Akumulace subakvatického kuželového tělesa hrubozrnných klastik v prostoru Kroměřiže a Ratají mohla být způsobena reaktivací zlomového pásma Hané. Toto pásmo hrálo dưležitou roli v počáteční fázi sedimentace karpatu (Francírek - Nehyba 2016). Pokud došlo závěrem karpatu k obnovení poklesů, mohlo vzniknout podmořské paleoúdolí, které pak bylo vyplňováno také materiálem přineseným z přilehlých zdvižených příkrovů. Kroměřížské souvrství by tak paleogeograficky představovalo lokální, tektonicky podmíněný fenomén.

\section{Závěry}

Sedimenty tzv. „pebbly mudstones“ (kroměřížské souvrství, karpat), zastižené vrty Rataje-1 a Kromeříž-1, lze podle rozdílných podílů štěrkové složky klasifikovat jako štěrkový kalovec (gravelly mudrock) a písčitý kalovec (sandy mudrock). Depozice facie je spojována s kohezivními úlomkovitými proudy, které jsou nejspíše součástí hrubozrnného subakvatického tělesa. Petrografie valounů identifikuje jako zdroj materiálu příkrovy Západních Karpat. Podle asociací detritických granátů byly hlavními zdroji materiálu facie tzv. "pebbly mudstones" sedimenty krosněnského a ždánicko-hustopečské souvrství. Paleogeograficky jsou tedy „pebbly mudstones“ fixovány ke zdviženým flyšovým př́krovům vnějších Západních Karpat. Syntéza publikovaných údajů a vlastních výsledků potvrzuje dosavadní interpretaci kroměřížského souvrství coby okrajové facie karpatské předhlubně, paleogeograficky vázáné $\mathrm{k}$ čelu př́íkrovů ždánické a slezské jednotky.

\section{Poděkování}

Práce vznikla jako součást specifického výzkumu na vysoké škole. Autoři děkují recenzentưm L. Mašterovi a P. Pálenskému a redakci GVMS za pripomínky, které vedly k upřesnèní údajů a zkvalitnění textu. 
Literatura

Adámek, J. - Brzobohatý, R. - Pálenský, P. - Šikula, J. (2003): The Karpatian in the Carpathian Foredeep (Moravia). - In: Brzobohatý, R. - Cicha, I. - Kováč, M. - Rögl, F. (eds.): The Karpatian, a Lower Miocene Stage of the Central Paratethys, 75-92, Masarykova Univerzita.

Altermann, W. (1986): The Upper Palaeozoic pebbly mudstone facies of peninsular Thailand and western Malaysia - Continental margin deposits of Palaeoeurasia. - Geologische Rundschau, 75, 371-381.

Benada, S. - Kokolusová, A. (1986): Nové poznatky o geologické pozici hrubých klastik karpatu ve střední části karpatské předhlubně na Moravě. - Zemní plyn a nafta 32, 1, 1-15.

Benada, S. - Drutarovský, Z. - Guryča, I. - Holzknecht, M. - Hrubý, B. - Jelínková, Ž. - Kotásek, V. - Koukolíček, R. - Králová, Z. - Svoboda, J. - Šelle, M. - Thonová, H. - Voborníková, J. (1983): Závěrečná zpráva o hlubokém strukturním vrtu Kroměřiž 1. - MS, archiv MND a. s. Hodonín.

Brzobohatý, R. - Cicha, I. (1993): Karpatská předhlubeň. In: Přichystal, A. - Obstová, V. - Suk, M. (eds.): Geologie Moravy a Slezska. - MZM a PřF MU, Brno, 123-128.

Di Celma, C. (2011): Sedimentology, architecture, and depositional evolution of a coarse-grained submarine canyon fill from the Gelasian (early Pleistocene) of the Peri-Adriatic basin, Offida, central Italy. - Sediment. Geol. 238, 233-253.

Francírek, M. - Nehyba, S. (2016): Evolution of the passive margin of the Peripheral Foreland Basin: an Example from the Lower Miocene deposits of the Carpathian Foredeep (Czech Republic). - Geologica Carpathica, 67, 1, 41-68.

Hanžl, P. - Krejčí, O. (1996): Geochemické rysy granitických valounů magurského flyše Chřibů a jejich provenience. - Geologické výzkumy na Moravě a ve Slezsku, 3, 56-58.

Hanžl, P. - Schitter, F. - Finger, F. - Krejčí, O. (1997): Datování granitu z valounu slepenců magurského flyše Chřibů. - Geologické výzkumy na Moravě a ve Slezsku, 4, 26-27.

Cháb, J. - Stráník, Z. - Eliáš, M. (2007): Geologická mapa České republiky 1 : 500 000. - Česká geologická služba. Praha.

Nichols, G. (2009): Sedimentology and Stratigraphy. - 419 s. Wiley-Blackwell. Second Edition. Chichester.

Otava, J. - Krejčí, O. - Sulovský, P. (1997): První výsledky studia chemismu granátů pískovců račanské jednotky magurského flyše. - Geologické výzkumy na Moravě a ve Slezsku, 4, 39-42.

Postma, G. (1984): Mass-flow conglomerates in a submarine canyon: Abrioja fan-delta, Pliocene, Southeast Spain. - In: Koster, E. H. - Stell, R. J., (eds.): Sedimentology of gravels and conglomerates, 237-258, Canadian Society of Petroleum Geologists.

Reineck, H. E - Singh, I. B. (1973): Depositional sedimentary environments: with reference to terrigenous clastics. Springer-Verlag, Berlin, 1-439.

Sohn, Y. K. - Kim, S. B. - Hwang, I. G. - Bahk, J. J. - Choe, M. Y. - Chough, S. K. (1997): Characteristics and depositional processes of large-scale gravelly Gilbert-type foresets in the Miocene Doumsan Fan Delta, Pohang Basin, SE Korea. - Journal of Sedimentary Research, 67, 130-141.

Stráník, Z. - Hrouda, F. - Otava, J. - Gilíková, H. - Švábenická, L. (2007): The Upper Oligocene-Lower Miocene Krosno lithofacies in the Carpathian Flysch Belt (Czech Republic): sedimentology, provenance and magnetic fabrics. - Geologica Carpathica 58, 4, 321-332.

Štelcl, J. (1993): Výsledky petrochemického studia krystalinických exotik račanské jednotky magurského flyše. - Zprávy o geologických výzkumech v roce 1991, 138-140.

Talling, P. J. - Masson, D. G. - Sumner, E. J. - Malgesini, G. (2012): Subaqueous sediment density flows: Depositional processes and deposit types. - Sedimentology, 59, 1937-2003.

Tucker, M. E. (2011): Sedimentary rocks in the field - a practical guide. - $234 \mathrm{~s}$. Wiley-Blackwell. Chichester.

Wagreich, M. (2003): A slope-apron succession filling a piggyback basin: the Tannheim and Losenstein Formations (Aptian-Cenomanian) of the eastern part of the Northern Calcareous Alps (Austria). - Mitteilungen der Österreichischen Geologischen Gesellschaft. 93, 31-54.

Zádrapa, M. (1977): Petrografické zhodnocení vrtu Rataje-2. - Zemní plyn a nafta, 22, 165-177. 